\title{
Evaluation of Safety in a Petroluem Refining Company: A Case Study on the Naphtha Hydro - Treating Unit (Nhu) Of Kaduna Refining and Petrochemical Company, Nigeria
}

\author{
${ }^{1}$ Otaru, A.J., ${ }^{2}$ Abdulkareem, A.S., ${ }^{3}$ Yusuf, Y.R., ${ }^{4}$ Odigure, J.O., ${ }^{5}$ Okafor, J.O. and ${ }^{6}$ Ibrahim, S. \\ ${ }_{1,2,3,4 \& 5}$ (Department of Chemical Engineering, Federal Univeristy of Technology, PMB 065, Gidan Kwanu, \\ Minna, Niger State, Nigeria) \\ ${ }^{6}$ (Ovecon Engineering and Consultancy, P.O. Box 1730, Zaria, Nigeria)
}

(Published in honor of Jacqueline C. Schindler)

\begin{abstract}
This research work is concerned with the evaluation of safety in a petroleum company (A case study on the Naphtha Hydro - treating Unit NHU of Kaduna Refining and Petrochemical Company, Nigeria). The evaluation was done using the formal safety review method which analyzes operation parameters such as temperatures of process equipment in actual operation with respect to temperature on the process flow diagram, and emissions like noise for a period of one year. The result shows that the major hazards in the NHU are heat emissions from process equipments like heaters and heat exchangers with emissions of poisonous gases such as $\mathrm{H}_{2} \mathrm{~S}, \mathrm{NH}_{3}$ and traces of heavy metal. The result also shows that the atmospheric condition at different months of the year has an adverse effect on the temperature of process equipment. This result also confirms that for most process industries like refineries, petroleum companies, and production companies, are associated with such hazards.
\end{abstract}

Keywords: Hazards, Kaduna, NHU, Refining, and Safety.

\section{Introduction}

The Nigerian economy depends heavily on income from crude oil exportation and the refined petroleum products to power industries for local consumption within Nigeria, in fact, it is a well known fact that the West African region relies to a great extent on Nigerian refined petroleum to oil their economy. It is also a fact that whenever refineries in Nigeria go down, a lot of hardship is experienced occasionally by long fuel queues in filling stations to outright unavailability of the product.

An oil refinery or petroleum refining industry is an industrial process plant where crude oil are been processed and refined into more useful petroleum products, such as gasoline, diesel, asphalt base, heating oil, and liquefied petroleum gas (Gary and Handwerk,1984). Oil refineries are typically large, sprawling industrial oil complexes with the extensive piping running throughout carrying streams of fluid between large chemical processing units (Leffler, 1985). In many ways oil refineries use much of the technology and can be thought of as type of chemical plant. In terms of operations, raw or unprocessed crude oil is not generally useful in industrial applications, although 'light sweet' (low viscosity, low sulphur) crude oil has been used directly as a fuel for steam vessel propulsion.

Naphtha is a colorless reddish brown volatile aromatic liquid, very similar to gasoline which also, is a fraction of crude oil that contains a number of flammable mixtures of hydrocarbon. It is a broad term covering among the lightest and most volatile fractions of the liquid hydrocarbon in petroleum (Prestvic, et al., 2004). In petroleum engineering, full range naphtha is defined as the fraction in petroleum boiling between $30^{\circ} \mathrm{C}$ and $200^{\circ}$ $\mathrm{C}$ and consists of a complex of hydrocarbon molecules generally having between 1 and 12 carbon atoms, it typically constitute $15-30 \%$ crude oil by weight, light naphtha is a fraction boiling between $30^{\circ} \mathrm{C}$ and $90^{\circ} \mathrm{C}$ and consist of molecules with $5-6$ carbon atoms. Heavy naphtha boils between $90^{\circ} \mathrm{C}$ and $200^{\circ} \mathrm{C}$ and consists of molecules with 6-12 carbons (Prestvic, et al., 2004). The purpose of the naphtha hydro-treating unit is to eliminate the impurities (such as sulphur, nitrogen, halogens, oxygen, water, olefins, di-olefins, arsenic and metal) form the feed that would otherwise affect the performance and lifetime of the reformer catalyst (Chiyoda, 1980). This is achieved by the use of selected catalyst like nickel, cobalt and molybdenum at optimum operating conditions except for water which is eliminated in stripper.

The hazardous nature of naphtha in the refinery (NHU) can be minimized or reduced by the provision of exhaust ventilation or other engineering controls to keep the airborne concentrations of the vapor below their respective threshold limit value and also ensuring that eyewash stations and safety showers are proximal to the work - station location (Sadighi et al., 2009) . Also in the case of large spill of naphtha, use of personal protective equipments such as splash goggles, full suit, gloves, vapor respirator, a self contained breathing 
apparatus should be used to avoid inhalation of the product. The time weighted average (TWA) of whole naphtha depends on the location where it is being used.

Due to the sensitive nature and high risk associated with refineries, the importance of safety cannot be overemphasized. A lot of loss in production has been experienced due to downtime damage and injuries. Also, the rigorous operations carried out in the naphtha hydro - treating unit, have exposed workers to hazards that pose treat to human health system. It is against this background that it is of immense important to evaluate these hazards and how they can be managed effectively so that workers can have a safe working environment. This work is focused on the safety evaluation in a petroleum refining company. The major objective of this research include investigating the safety in the Naphtha Hydro - treating Unit in the petrochemical industry particularly in the Southern part of Kaduna, Nigeria to determine the current state of hazards and how it can be minimized.

\section{Research Methodology}

The method of evaluating safety in the naphtha hydro treating unit of the Kaduna Refining and Petrochemical Company in this research work is based on the approach of "the formal safety review process". The required information were extracted from the process flow diagram (PFD) and the NHU operating manual and tabulated as shown in Table 1. It also involves collection of process parameters such as temperature, and flow rate in actual operations for a period of one year. This is done in order to compare the deviation of the temperatures of process equipment and that in the process flow diagram so as to evaluate the difference in the heat emitted from each of the process equipment and also relate the hazardous effect on the health of the workers in the Naphtha Hydro - treating Unit plant. This research also involves collection of data of noise pollution within the above mentioned period in order to evaluate the Time Weighed average (TWA) at which the Kaduna Refining and Petrochemical Company operates and relating the K.R.P.C value with the Time Weighted Average of the Occupational Safety and Health Administration (OSHA) of the United states Department of Labor (USDL).

Table 1: NHU Stream Data Extracted from Process Flow Diagram (PFD).

\begin{tabular}{llll}
\hline S/NO. & Stream No. & Stream Name & Heat Duty $(\mathrm{Kcal} / \mathrm{hr}) \times 10^{6}$ \\
\hline 1 & $11 \mathrm{E} 01 \mathrm{~A}-\mathrm{C}$ & NHU Feed/Effluent exchanger & 24.16 \\
2 & $11 \mathrm{H} 01$ & NHU Reactor Charge Heater & 6.38 \\
3 & $11 \mathrm{R} 01$ & NHU Reactor Effluent & 24.16 \\
4 & $11 \mathrm{~A} 01$ & NHU Reactor Effluent Cooler & 5.39 \\
5 & $11 \mathrm{E} 02$ & NHU Reactor Effluent Trim Cooler & 0.52 \\
& & NHU Low Pressure Separator Charge & \\
6 & $11 \mathrm{E} 05$ & cooler & 0.35 \\
& & NHU Stripper Feed & 6.41 \\
7 & $11 \mathrm{C} 01$ & NHU Stripper Feed Bottom Exchanger & \\
8 & $11 \mathrm{E} 03$ & NHU Stripper OH Condenser & 6.41 \\
& & NHU Stripper OH Trim Condenser & 0.39 \\
9 & $11 \mathrm{~A} 02$ & NHU Stripper Reboiler heater & \\
10 & $11 \mathrm{E} 04$ & NHU Splitter & 14.70 \\
& & NHU Splitter Reboiler & 14.70 \\
11 & $11 \mathrm{H} 02$ & NHU Splitter OH Condenser & 4.28 \\
12 & $11 \mathrm{C} 02$ & NHU Light Naphtha Trim Cooler & 0.23 \\
13 & $11 \mathrm{E} 06$ & & \\
15 & $11 \mathrm{~A} 03$ & NHU Heavy Naphtha Cooler & 2.10 \\
16 & $11 \mathrm{E} 07$ & NHU Stripper OH Trim Condenser & 0.17 \\
17 & & & \\
\hline
\end{tabular}

\section{Formal Safety Review Process}

The formal safety review is used for new process, substantial changes in existing processes, and processes that need an updated review. The formal safety review is a three - step procedure. Which consist of:

1. Preparing a detailed formal safety review report.

2. Having a Committee to review the report and inspect the process

3. Implementing the recommendations 


\section{Description of the Naphtha Hydro - treating based on formal safety review method.}

Stage I: Introduction

Overview or summary: This will be done at the end of the of the formal safety review process of the Naphtha Hydro - treating Unit. It is based on the results obtained from the analysis of temperature, emissions of chemicals such ammonia, $\mathrm{H}_{2} \mathrm{~S}$, traces of heavy metals like Lead, arsenic, copper and noise pollution.

Process overview: The Naphtha Hydro - treating Process is a catalytic refining process employing a selected catalyst and a hydrogen-rich gas stream. Decompose organic sulphur, oxygen and nitrogen compounds contained in hydrocarbon fractions. In addition, hydro - treating removes Organo - metallic compounds and saturates olefinic compounds.

Operation of these units involves the coordination of different activities to be carried out in an efficient and safe manner. It also requires a detailed knowledge of the process, proper planning, safe plant operation, effective supervision and monitoring.

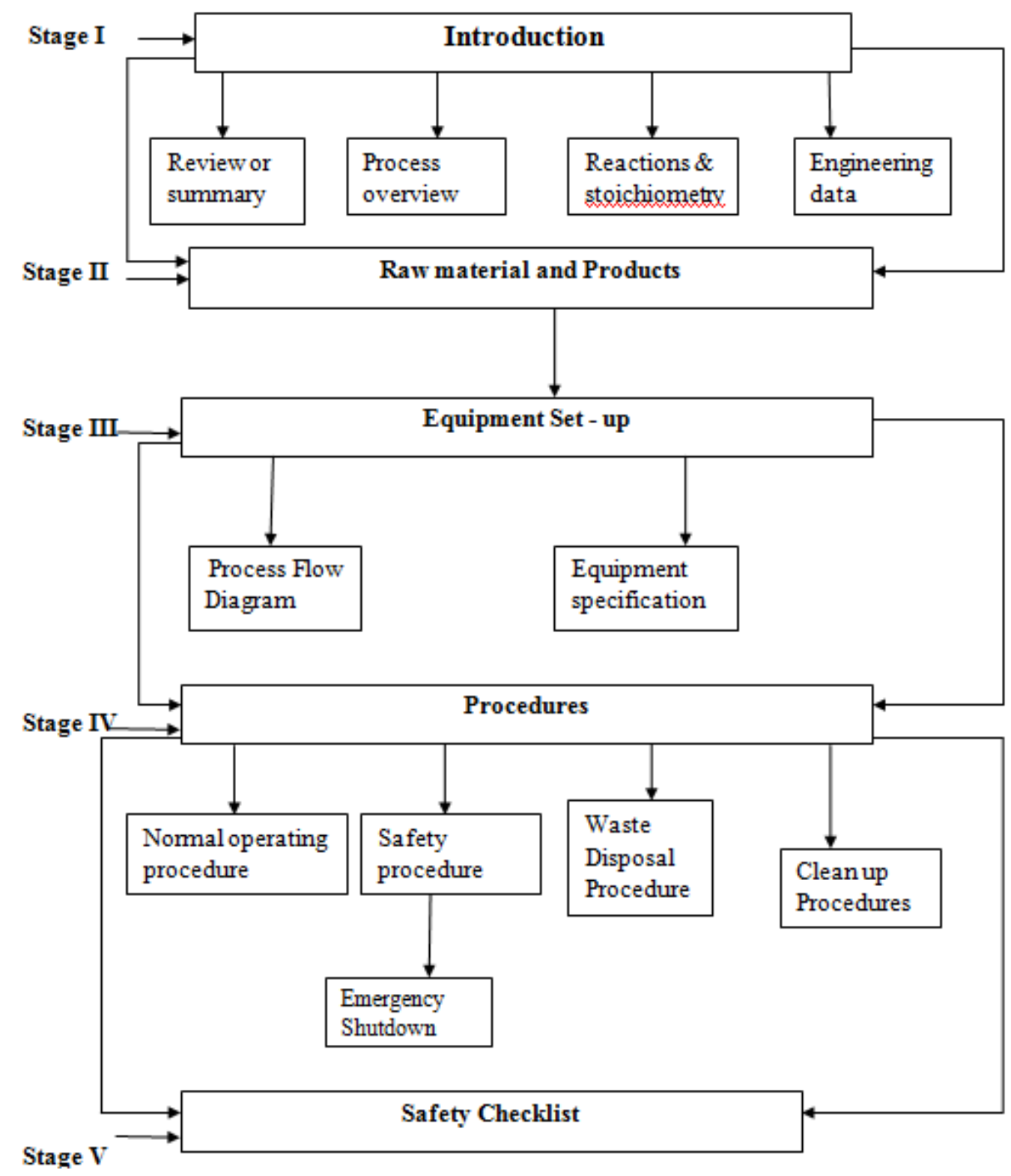

Figure 1: The Formal Safety Review Steps Diagrammatical Representation The major operation of the Naphtha Hydro - treating Unit involves;

1. Removal of impurities by reaction with hydrogen

2. Separation of Whole naphtha into its fractions. 
1. Impurities Contained in whole Naphtha are;

i. Sulfur in form of mercaptans, sulfides, disulfides, thiophenes etc.

ii. Nitrogen in the form of pyrroles, pyridines.

iii. Oxygen in the form of phenols, diphenols.

iv. Metals such as Lead ,Copper, Iron, Nickel ( Organo - metallic compounds)

2. Fractions obtained from whole naphtha separation in NHU

i. Liquefied Petroleum Gas.

ii. Light Naphtha.

iii. Heavy Naphtha.( Treated)

\section{Reaction and stoichiometry}

The reactions taking place in the NHU are grouped into two types, thus:

Hydrogenation reactions: This consists mainly of saturation of Olefinic compounds and in the saturation of Aromatic Compounds. Olefins are unsaturated hydrocarbons having the general formula $\mathrm{C}_{\mathrm{n}} \mathrm{H}_{2 \mathrm{n}}$ and are characterized by relatively great chemical activity (unstable structure). They tend to polymerize or in the presence of hydrogen become saturated compounds or paraffinic compound. The presence of olefins in the feed is negligible. Aromatics are ring compounds characterized by alternate double bond. In the presence of hydrogen they tend to turn into naphthenic compounds. Under normal conditions these reactions are generally weak, however pressure favors them. These reactions must be avoided so as to avoid an increase of the work load of the reforming catalyst.

Hydro-refining reactions: These reactions are related to the desulfurization, denitrification, deoxygenation, and demetalization of the feed (whole naphtha).

Desulfurization reaction: This is a hydro - refining reaction in which sulphur compounds are transformed into hydrogen sulphide and hydrocarbon compound. The sulphur compounds of straight - run naphtha are mainly mercaptan, sulphides, disulfides, and polysulphides which can be easily transformed. These reactions are illustrated below:

$\mathrm{R}-\mathrm{SH}+\mathrm{H}_{2} \longrightarrow \mathrm{RH}+\mathrm{H}_{2} \mathrm{~S} . \quad$ (General equation for the reaction).

\section{Mechanism for the general equation of reaction.}

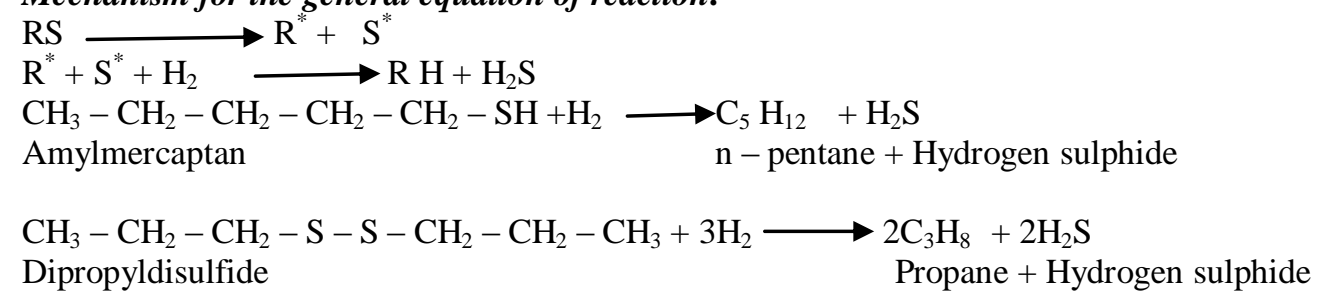

It is more difficult to eliminate the sulphur contained in cyclic compounds of aromatic character like thiophenes, etc.
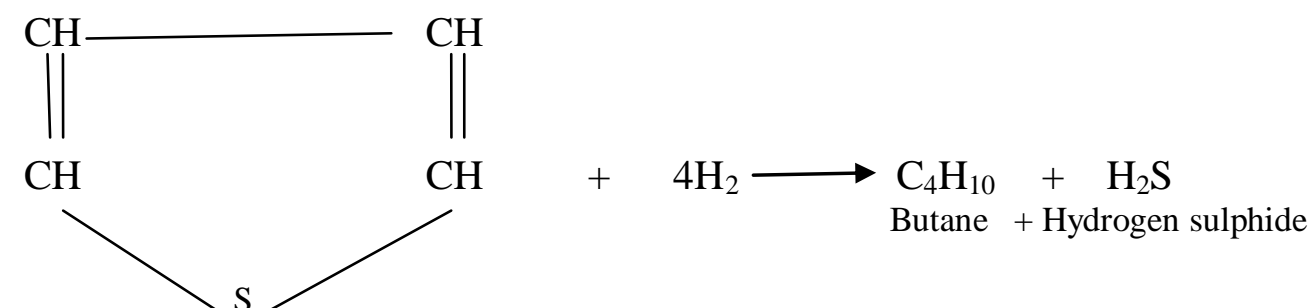

Desulphurisation reactions are exothermic, thus 17 to $67 \mathrm{Kcals}$ for each mole of hydrogen

Denitrification reaction: This is a hydro - refining reaction by which nitrogen compounds are transformed into ammonia and hydrocarbon. The nitrogen compounds are mainly pyrroles, pyridines which have a cyclic structure with an aromatic character and are decomposed at lower rate than the desulphurization reactions. Nevertheless nitrogen elimination is practically completely achieved. This is illustrated below; 

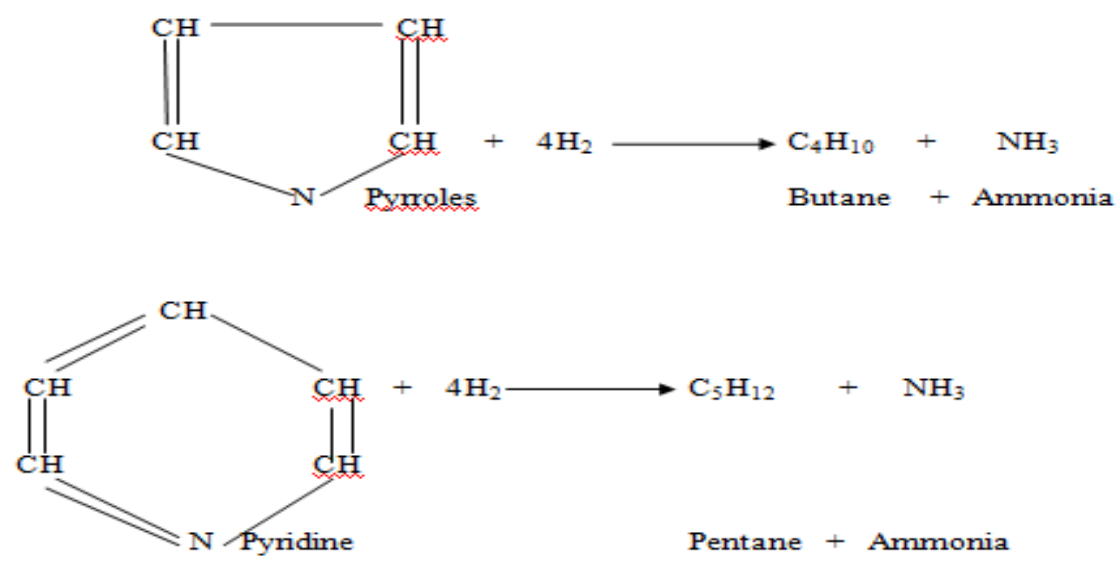

De - oxygenation reaction: This is a hydro - refining reaction by which oxygen compound are transformed into water and hydrocarbon compounds. These oxygen compounds are mainly phenols. Phenols are cyclical compounds derived from benzene by substituting an atom of hydrogen with an hydroxyl. This is illustrated below;

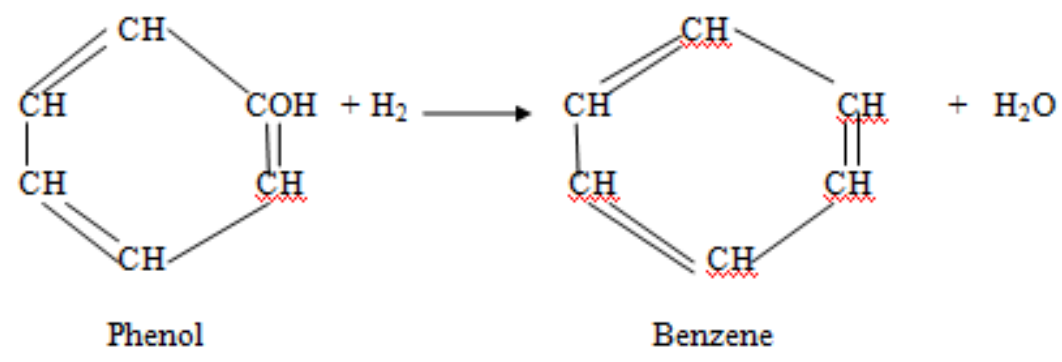

De-metallization reaction: This is reaction where by metals present in the feed (whole naphtha) are associated with hydrocarbons and their removal is obtained by replacement with hydrogen. Metals released are in pure form and are absorbed by the catalyst support (alumina). Generally metals favors cracking with consequent deposition of coke, but due to their minute quantities in the hydro - treated feedstock, they are not considered a problem for the running of the unit. However the catalyst has a very high metal absorption capacity. This is illustrated below;

$\mathrm{PbR}+\mathrm{H}_{2} \longrightarrow \mathrm{RH}+\mathrm{Pb}$

Engineering data: The operating parameters for the naphtha hydro treating unit is; Temperatures, Pressures Flow rates and relevant physical property data for the NHU

\section{Stage II}

Raw material and products.

The raw material handled in the Naphtha hydro - treating unit is mainly whole naphtha or straight - run naphtha. At the end of the process, Liquefied Petroleum Gas (LPG), Light Naphtha and treated Heavy Naphtha are obtained. The hazards associated with the NHU plant are listed below:
a. Emission Hazard.
b. Fire and exposure hazard.
c. Noise pollution.
d. Mechanical failure etc.

\section{Emission hazards}

Emissions associated with the Naphtha Hydro - treating Unit is as a result of spills and leakages from pipes, reactors, columns, heaters, and heat exchangers etc. These emissions can be analyzed or evaluated based on the nature of reactions taking place in the NHU reactor, and impurities such as sulphur, nitrogen, oxygen, traces of heavy metals to be removed from naphtha which in turn after the reaction are removed in the form of sulphides, mercaptans, disulphides, thiophenes, pyrroles, pyridines, phenols, diphenoles, lead, iron and nickel to obtain the desired products, which under normal condition are harmful to the human body mechanism. Table 2 below explains these emissions and how they can be minimized or handled in order to ensure safe working environment or atmosphere. 
Table 2: Effects of Emissions from the NHU Plant

\begin{tabular}{|c|c|c|}
\hline $\begin{array}{l}\text { Emissions/ } \\
\text { impurities }\end{array}$ & Health Hazards & $\begin{array}{l}\text { Actions to be taken to minimize the } \\
\text { hazard }\end{array}$ \\
\hline $\begin{array}{l}\text { Hydrogen } \\
\text { sulphide }\end{array}$ & $\begin{array}{l}\text { Irritating to the skin and eyes. Inhalation } \\
\text { of high concentration can cause dizziness, } \\
\text { headache, and nausea. Exposure to higher } \\
\text { concentrations can result in respiratory } \\
\text { arrest, coma, or unconsciousness and } \\
\text { death. Exposures which do not result in } \\
\text { death may cause long-term symptoms } \\
\text { such as memory loss, Paralysis of facial } \\
\text { muscles, or Nerve tissue damage. Chronic } \\
\text { over exposure may cause permanent eye } \\
\text { damage. }\end{array}$ & $\begin{array}{l}\text { Adequate ventilation, Local exhaust } \\
\text { ventilation is preferred, because it } \\
\text { prevents Hydrogen Sulphide } \\
\text { dispersion into the work place by } \\
\text { eliminating it from its source. If } \\
\text { appropriate, automatic monitoring } \\
\text { equipment should be installed to } \\
\text { detect the level of Hydrogen Sulphide, } \\
\text { the presence of potentially explosive } \\
\text { air-gas mixtures, and oxygen. Eye } \\
\text { wash stations/safety showers should } \\
\text { be close areas of such nature. }\end{array}$ \\
\hline Ammonia & $\begin{array}{l}\text { Mild concentrations of product will cause } \\
\text { conjunctivitis. Contact with higher } \\
\text { concentrations of product will cause } \\
\text { swelling of the eyes and lesions with a } \\
\text { possible loss of vision, caustic like dermal } \\
\text { burns and inflammation, corrosive } \\
\text { irritating on the upper respiratory system } \\
\text { and all mucous tissue depending on the } \\
\text { concentration inhaled. It may cause } \\
\text { burning sensations, coughing, wheezing, } \\
\text { shortness of breath, headache, } \\
\text { nausea, with eventual collapse. }\end{array}$ & $\begin{array}{l}\text { All personnel should be evacuated } \\
\text { from affected area. Appropriate } \\
\text { protective equipment should be used. } \\
\text { If leak is in user's equipment, it } \\
\text { should be certain to purge piping with } \\
\text { inert gas prior to attempting repairs. }\end{array}$ \\
\hline $\begin{array}{l}\text { Heavy } \\
\text { metals } \\
\text { (lead, } \\
\text { copper, iron } \\
\text { ) }\end{array}$ & $\begin{array}{l}\text { Skin, respiratory disorders, kidney and } \\
\text { liver disorders may be aggravated by } \\
\text { prolonged over-exposures to the dusts or } \\
\text { fumes generated by these products. } \\
\text { Additionally, lead over-exposures can } \\
\text { cause adverse effects on the human } \\
\text { reproductive system }\end{array}$ & $\begin{array}{l}\text { Adequate ventilation should be used } \\
\text { to ensure exposure levels are } \\
\text { maintained below limits. Prudent } \\
\text { practice is to ensure eyewash/safety } \\
\text { shower stations are available near } \\
\text { areas where these products are used. }\end{array}$ \\
\hline
\end{tabular}

\section{Fire and Exposure hazards}

Fire: Naphtha being a flammable liquid with an ignition temperature of approximately $229^{\circ} \mathrm{C}$, flash point greater than $38^{\circ} \mathrm{C}$, flammable limit in air of $0.8 \%-5.0 \%$ with burning rate of $4 \mathrm{~mm} / \mathrm{min}$ with an electrical hazard classification of 1 and group D hazard and also a combustible fluid may lead to fire in the NHU plant as a result of some activities carried out during the operation of the pant. An example of such activity is the back firing of the heater during observation of the heater through the bottom holes. Also severe burns may result from leakages from flanges in the pipes. Fires arising from such source can best be extinguished with the use of dry chemicals, $\mathrm{CO}_{2}$, foam and cool exposed containers with water. In cases of emergency the fire department should be called upon, all health and pollution control agencies should be notified and all water intakes should be protected.

\section{Equipment set - up}

Stage III

Equipment description: This describes the configuration of the equipment with the use of sketches or process flow diagram of the various equipment in the NHU plant.

Equipment specifications: Table 3 identifies various process equipments with model number; it also provides other physical data and design information associated with the equipments in the NHU plant.

Procedure.

Stage IV

Normal operation procedures: The normal operation of the NHU plant is;

1. 11PV002B on the surge drum is off gas line is opened to equalize 11D05 to the flare. 
2. An inventory of naphtha from 51TK92 in 11D05, 11D04, 11C01 and 11C02 and the reboiler circuit is established.

3. Reboiler circulation is started up.

4. Following the fired heater start - up standing instructions the pilots in 11H02 is lighted.

5. 11A02/03is started when required.

6. $11 \mathrm{H} 02$ is fired at $40^{\circ} \mathrm{C} / \mathrm{hr}$ and a total reflux is established.

7. Corrosion inhibition injection is started.

8. Heavy naphtha is lined up to 51TK92

9. When CDU naphtha becomes availably cut into the work - up section, light naphtha is lined up to $51 \mathrm{TK} 12$.

10. 11H02 firing and tower conditions are adjusted for steady state operation.

Safety procedures: This provides description of the unique concerns associated with the equipment and materials and specific procedures used to minimize risk in the NHU plant. This includes:

Emergency shutdown: This describes the procedure used to shutdown the equipment if an emergency should occur in the NHU plant. This includes major leaks, reactor runaway, and loss of electricity, water and air pressure.

\section{General emergency shutdown procedure}

Emergency shutdown is made to maintain the pressure and the liquid level in the equipment at the normal operating level so that the unit can be restarted easily.

With the following actions, the unit will be in a bottled up condition. Generally the unit can be held in this condition until the emergency situation is removed, otherwise continue the shutdown of the unit by referring to the normal shutdown procedure.

For protection of the hydro-treating catalyst, follow these rules when possible:

(a) Avoid too high a temperature of the catalyst.

(b) Avoid having hydrocarbons present on the catalyst when hydrogen partial

Pressure is too low.

(c) Avoid too quick depressurizing of the reactor section.

NHU Reactor Section General Emergency Shutdown Procedure

In a case where the NHU makeup gas is stopped or the catalytic reforming unit (CRU) should be shut down immediately, which cause to cease the hydrogen production, the naphtha hydro-treating unit (NHU) should be shut down immediately.

(a) Cut off the main fuels to the NHU reactor charge heater $(11 \mathrm{H} 01)$ by turning the manual stop switch (HS-001).

Figure 2: Process Flow Diagram of the Naphtha Hydro - Treating Unit Plant

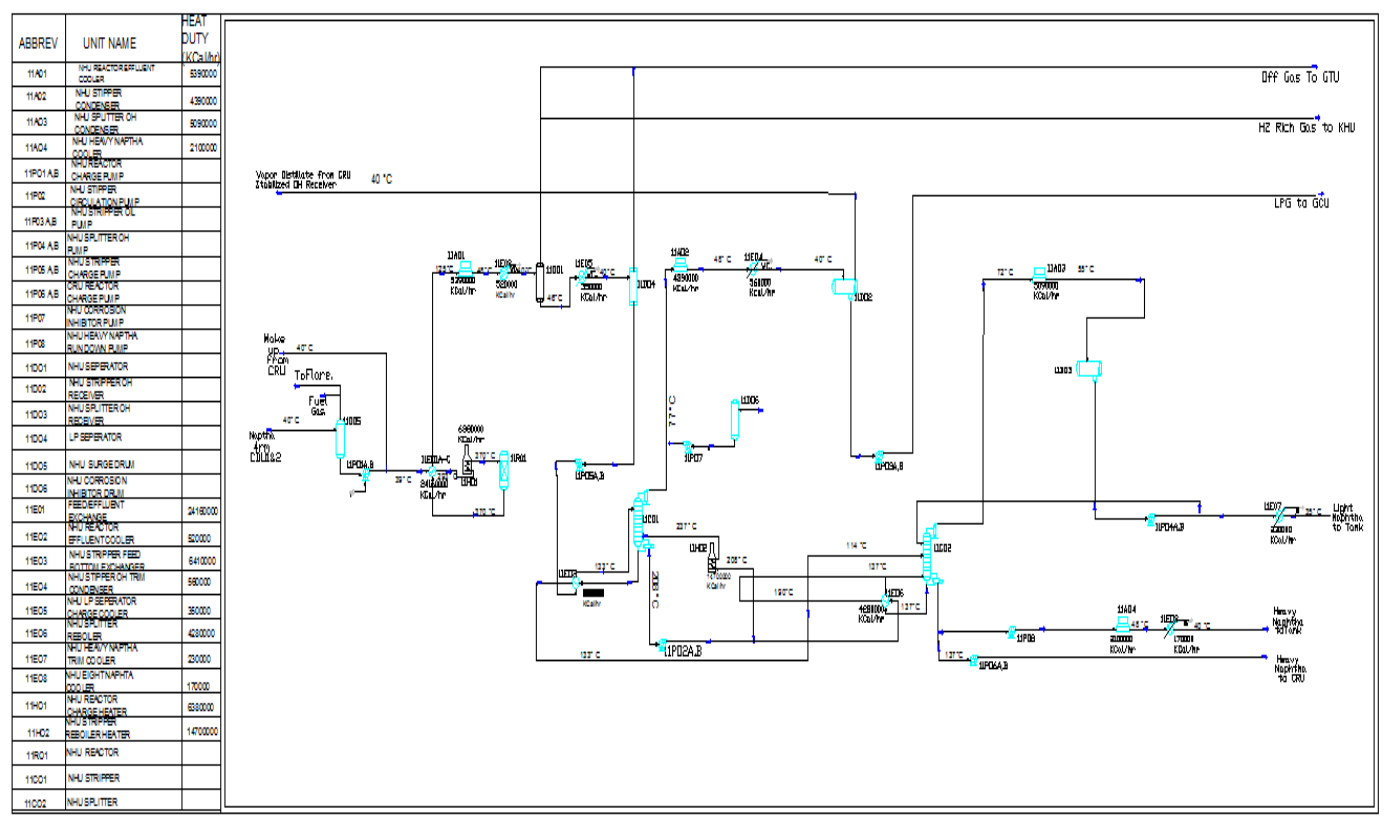




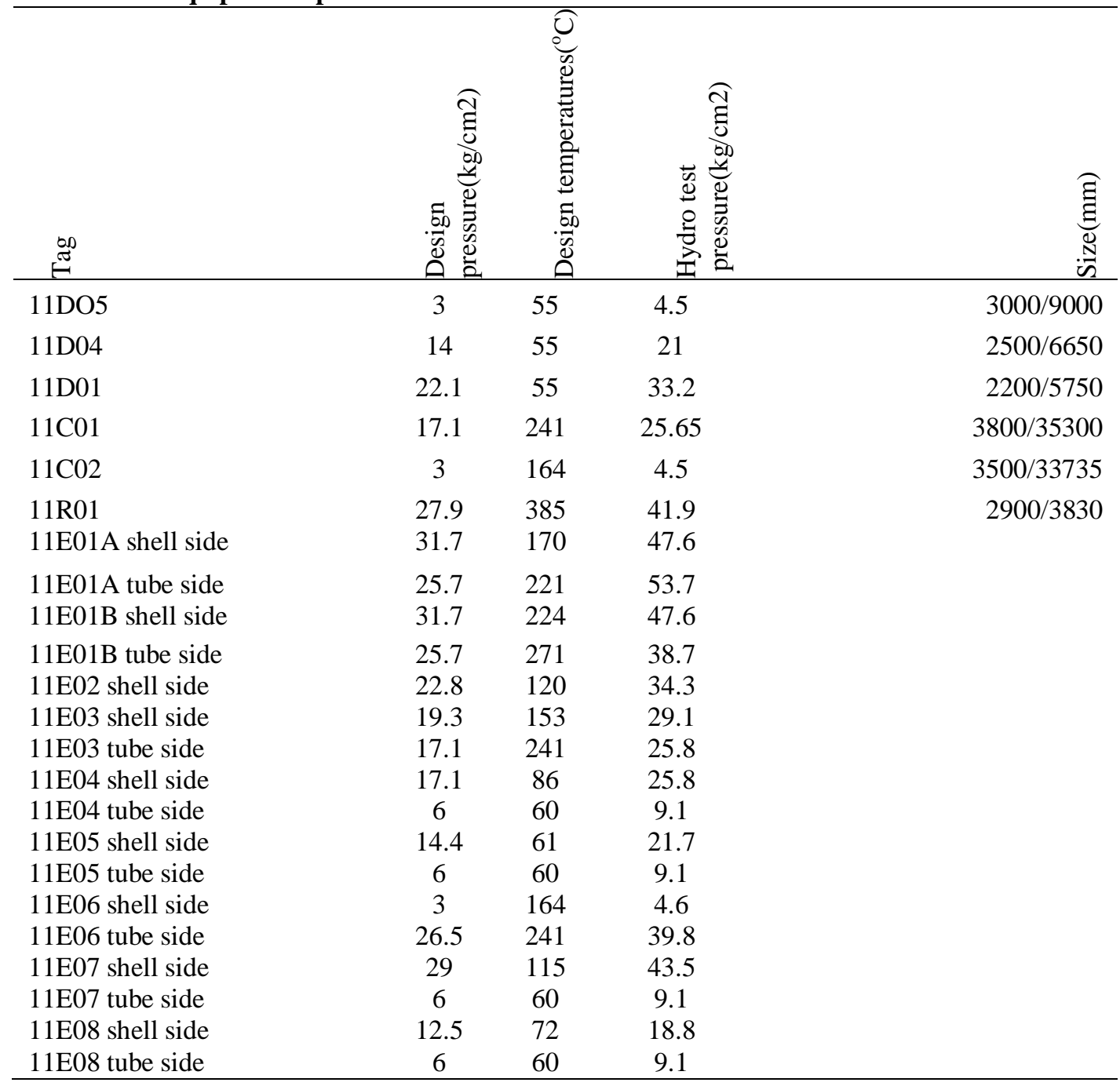

Note

(1)The pilot burner firing continues.

(2) For any emergency situation which appears as low flow in the NHU makeup gas, the Main Fuels are automatically cut off by the emergency interlock system.

(3) Isolate main fuel supply and atomizing steam lines. If possible, close burner valves.

(b) At the same time, stop the NHU reactor charge pump (11P01A or B) by pushing the Manual stop button (HS-002) and close the NHU reactor feed flow control valve (FV-001) Manually. Close the discharge valve of the pump as early as possible.

Note

Divert whole naphtha of the crude distillation unit No. 1 and No. 2 (CDU-1 \& CDU-2) to the light slop tank as early as possible.

1. The CRU reactor charge pump (11P06A or B) have been stopped due to requirement in the catalytic reforming unit (CRU). Otherwise stop 11P06A or B and close the CRU reactor feed flow control valves (12FV-014/ 016) manually. Close the discharge valve of the pump as early as possible.

(c) Immediately close the NHU stripper feed flow control valve (FV-011) and stop the NHU stripper charge pump (11P05A or B).

Close the block valve at FV-011 as early as possible.

(d) Block off the hydrogen rich KHU makeup gas line (3"-GH-11009) at the Battery limit.

Note

The hydrogen rich NHU makeup gas has been stopped and the pressure control Valve (PV-010) on the NHU HP separator off-gas line (4"-GH-11007) has to be 
Closed automatically.

(e) Close the NHU HP separator level control valve (LV-002) manually and close the block valve at LV-002.

(f) Watch the NHU reactor bed temperature indicators (TJI-006 010). If a temperature rise is observed, depressurize the NHU reactor section to the fuel gas system or the flare.

Watch the heater coil skin temperature indicators (TJI-016 019). If necessary, cut off the pilot fuel to $11 \mathrm{H} 01$, put snuffing steam into the firebox and open the stack damper to avoid coil overheating.

NHU work-up section general emergency shutdown procedure

(1) Total Reflux Operation: When the NHU reactor section should be shut down immediately, keep the NHU stripper and the NHU splitter operating under total reflux, if possible.

(a) Immediately close the NHU splitter feed flow control valve (FV-013) manually.

(b) Close the NHU stripper OH receiver, NHU splitter and NHU splitter OH receiver level control valves (LV007/008/009) manually.

(c) Stop the NHU corrosion inhibitor pump (11P07).

(d) Continue the NHU stripper (11C01) and the NHU splitter (11C02) operating under total reflux.

(2) Emergency Shutdown

If the NHU work-up section should be shut down immediately, apply the following procedure:

(a) Cut off the main fuels to the NHU stripper re-boiler heater (11H02) by turning the manual stop switch (HS003).

\section{Note}

The pilot burner firing continues.

Isolate main fuel supply and atomizing steam lines. If possible, close burner valves.

(b) Close the temperature control valve (TV-008) manually to stop oil circulation through the NHU splitter reboiler (11E06).

(c) Immediately close the NHU splitter feed flow control valve (FV-013) manually. Close block valve at FV013 as early as possible.

(d) Close the NHU stripper OH receiver, NHU splitter and NHU splitter $\mathrm{OH}$

Receiver level control valves (LV-007/008/009) manually.

(e) Stop the NHU stripper OH pump (11P03A or B) and the NHU splitter OH pump (11P04A or B).

(f) Stop the NHU corrosion inhibitor pump (11P07).

(g) Continue the re-boiler circulation.

Note

If the re-boiler circulation cannot be maintained, watch the heater coil temperature indicators (TJI-035 038). If necessarily, cut-off the pilot fuel to $11 \mathrm{H} 02$ put snuffing steam and opens the stack damper to avoid coil overheating.

Waste disposal Procedure: Most waste generated in the NHU plant is sent to the flare.

Cleanup procedures: Weakly hand picking of dirt around the unit

(Housekeeping)

\section{Safety Checklist}

Stage V

The following are to be checked before any start is made in the NHU plant;

1. NHU work - up section in - line with feed from CDU. Heavy naphtha run down to 51TK92, light naphtha to slope.

2. Reactor section air free and under $0.2 \mathrm{~kg} / \mathrm{cm}^{2} \mathrm{~N}_{2}$ with $\mathrm{O}_{2}$ content less than $0.2 \%$.

3. CRU in - line with feed from 51TK01A/B producing sufficient hydrogen.

4. NHU HP separator off - gas lined up to GTU.

\section{Results and Discussion}

The importance of safety in process plant especially in process developing countries like Nigeria cannot be overemphasized. This is due to the fact that there are no standard practices in place to check the activities of process industries on the health of workers as compared to developed countries. Aside from the risk that safety posed on the workers, it is also a source of risk to the physical assets of companies. Hence, there need to understand and identify the possible root of accidents for the purpose of eliminating or minimizing them.

This study was necessitated by the importance of petroleum as a major source of income to the Nigerian economy. It is also worth of mentioned that safety is based on the physical mechanics and chemistry attributes of the plants. The present studies graphically present and discuss the results obtained during the safety evaluation of the Naphtha Hydro - treating Unit NHU of Kaduna Refining and Petrochemical Company, Nigeria. 
Figure $3-14$ is the graphical representation of the highest temperature both for inlet, outlet, top and bottom of NHU equipments for the months of the year 2011. The equipments are heater surge drum (11D05), reactor charge heater (11H01), NHU reactor (11R01) inlet, NHU reactor (11R01) outlet, feed effluent exchanger (11E01), NHU separator (11D04), NHU stripper(11C01) bottom, stripper (11C01) top, NHU splitter (11C02) bottom, and the NHU stripper reboiler heater $(11 \mathrm{H} 02)$.

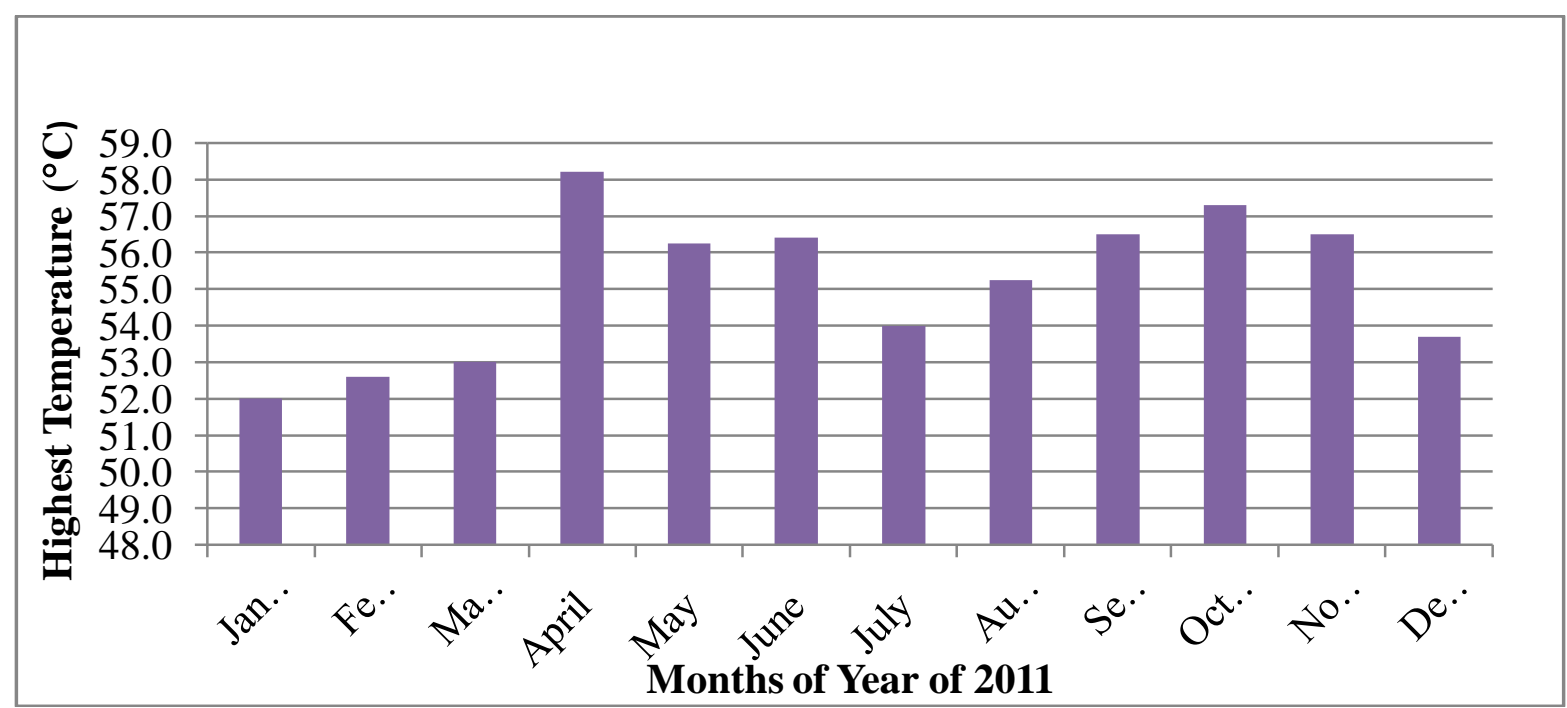

Figure 3: Graph of Highest Temperature $\left({ }^{\circ} \mathrm{C}\right)$ of 11D05 against Months for Year 2011

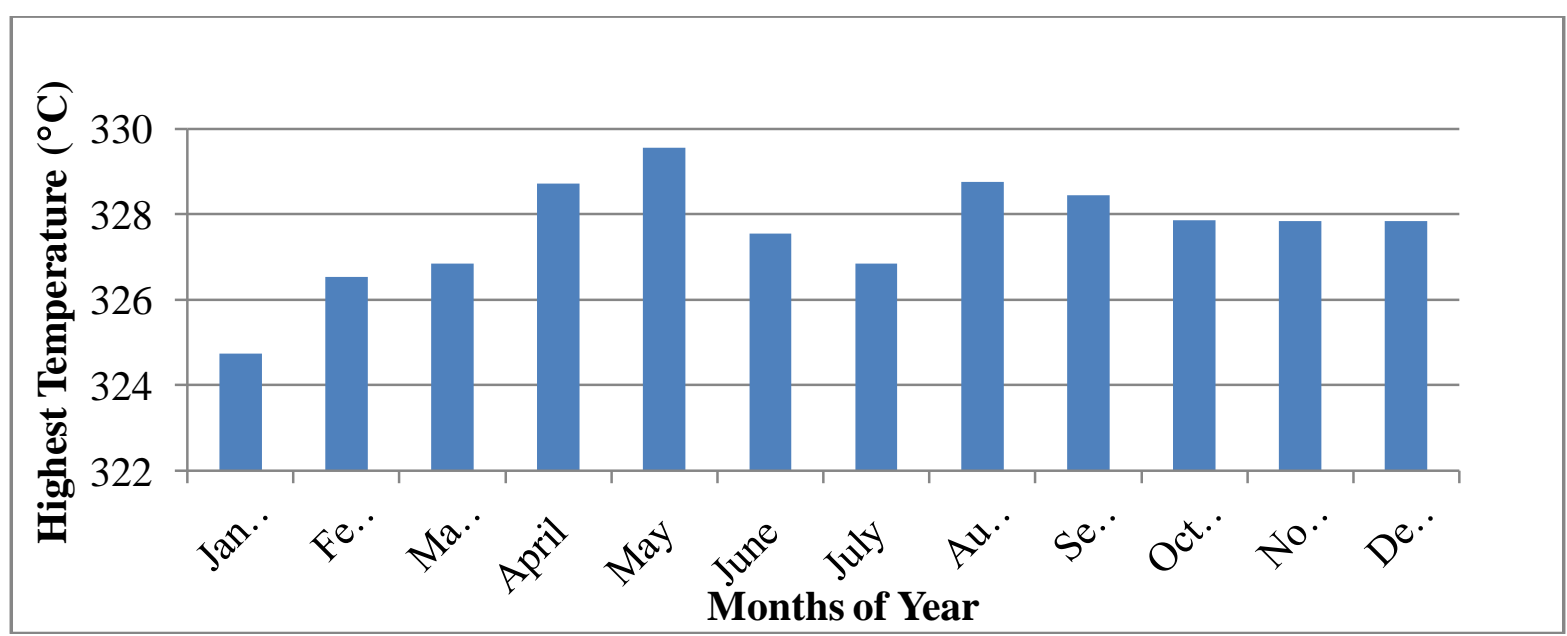

Figure 4: Graph of Highest Temperature of 11H01 against Months of Year 2011.

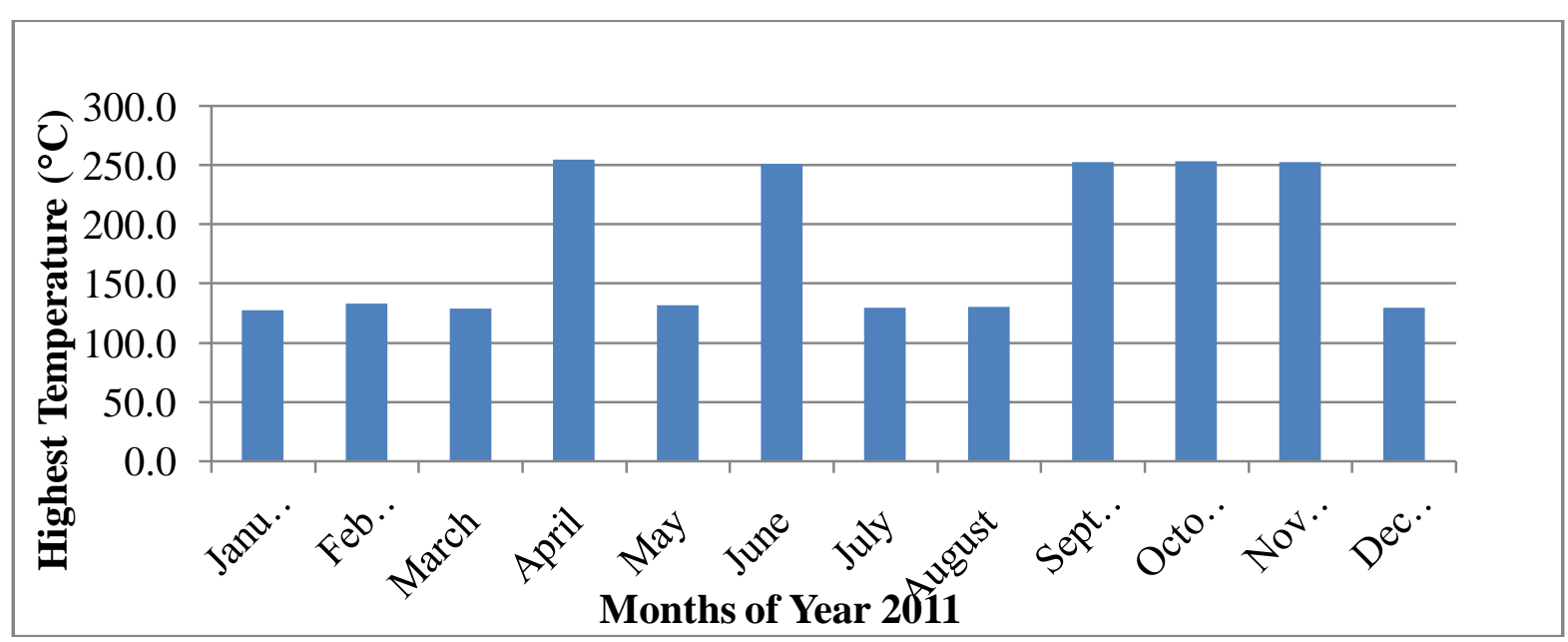

Figure 5: Graph of Highest Temperature of 11E01 against Month of Year 2011 


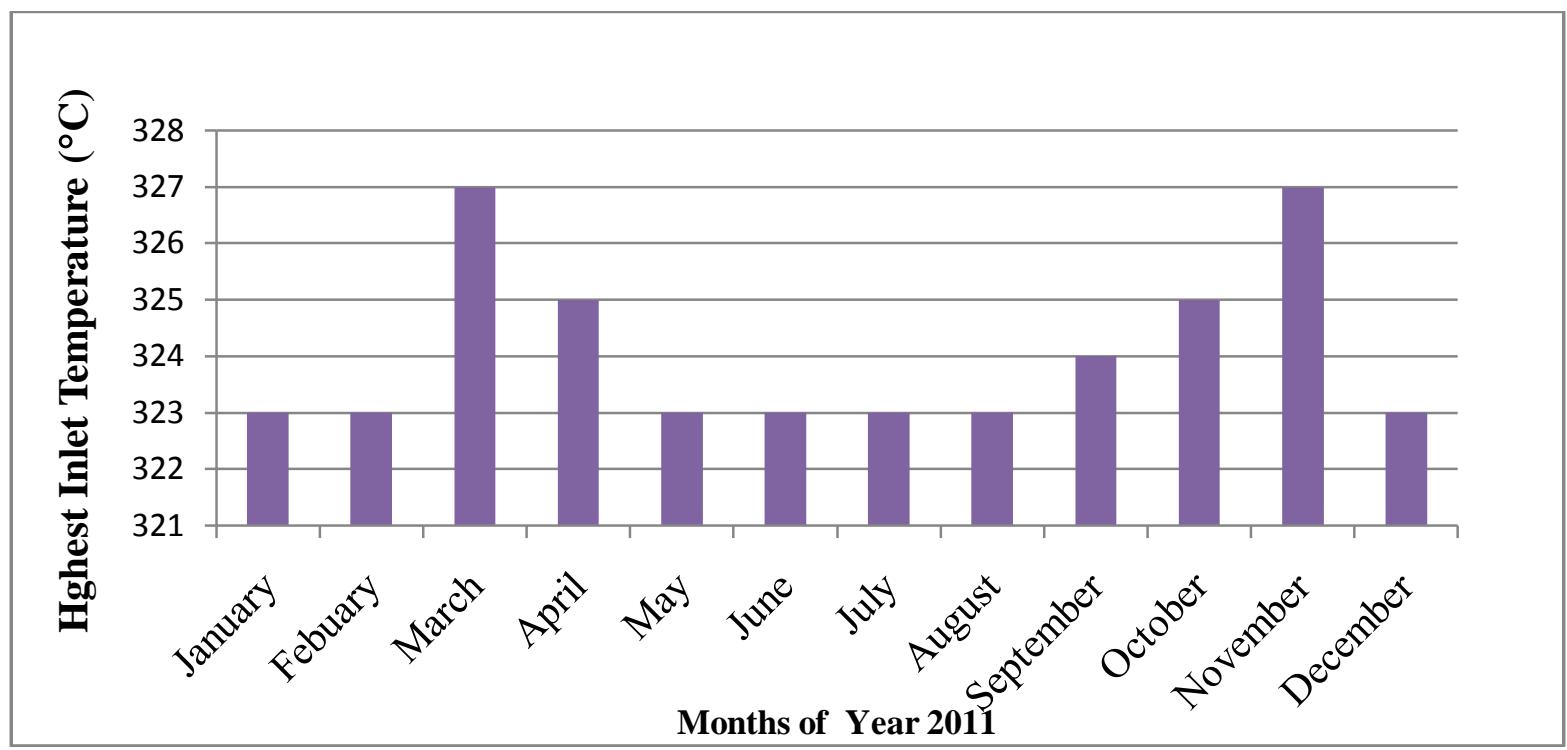

Figure 6: Graph of Highest Inlet Temperature of 11R01 against Months of Year 2011

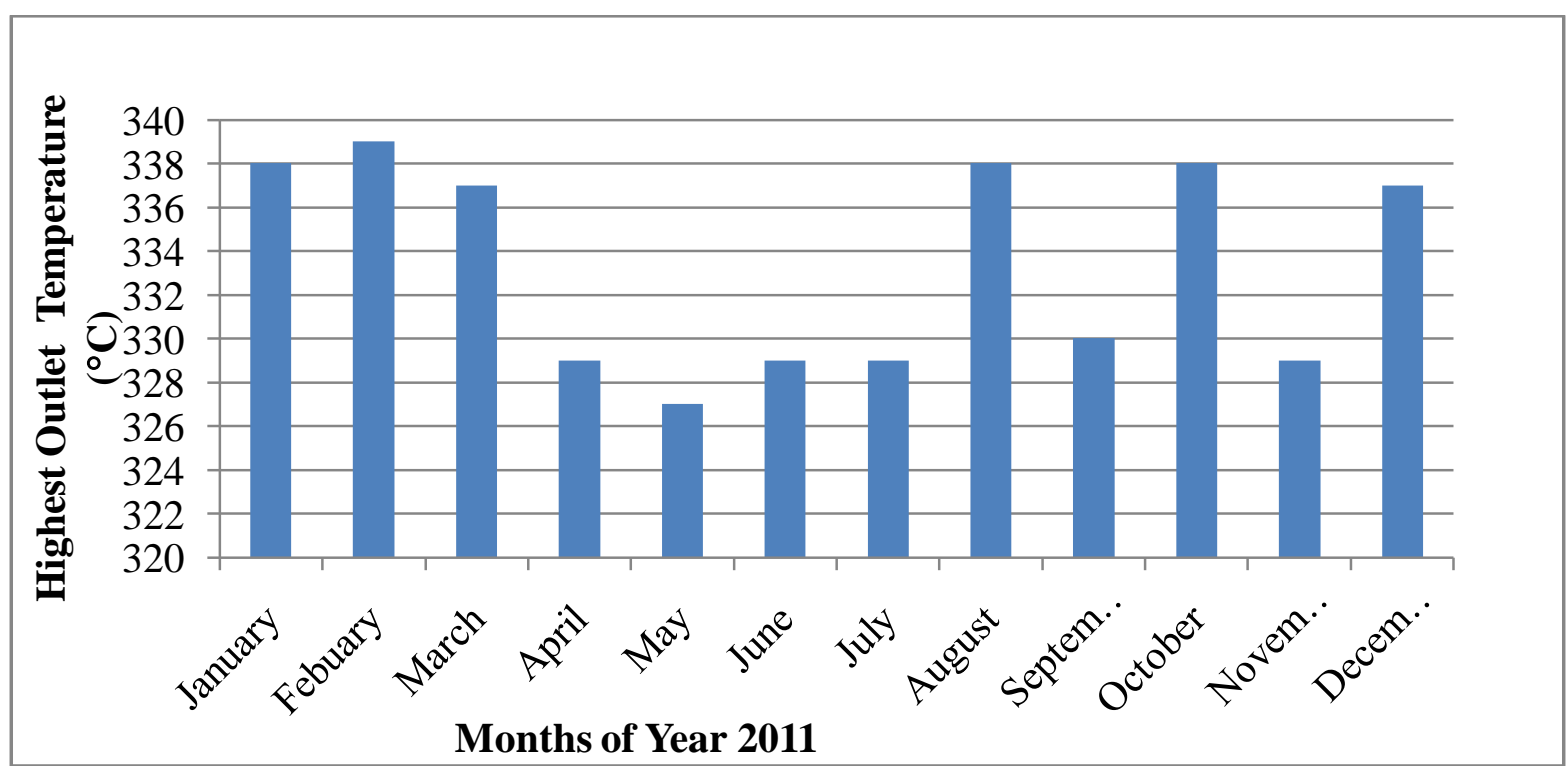

Figure 7: Graph of Highest Outlet Temperature $\left({ }^{\circ} \mathrm{C}\right)$ of 11R01 against Months for Year 2011

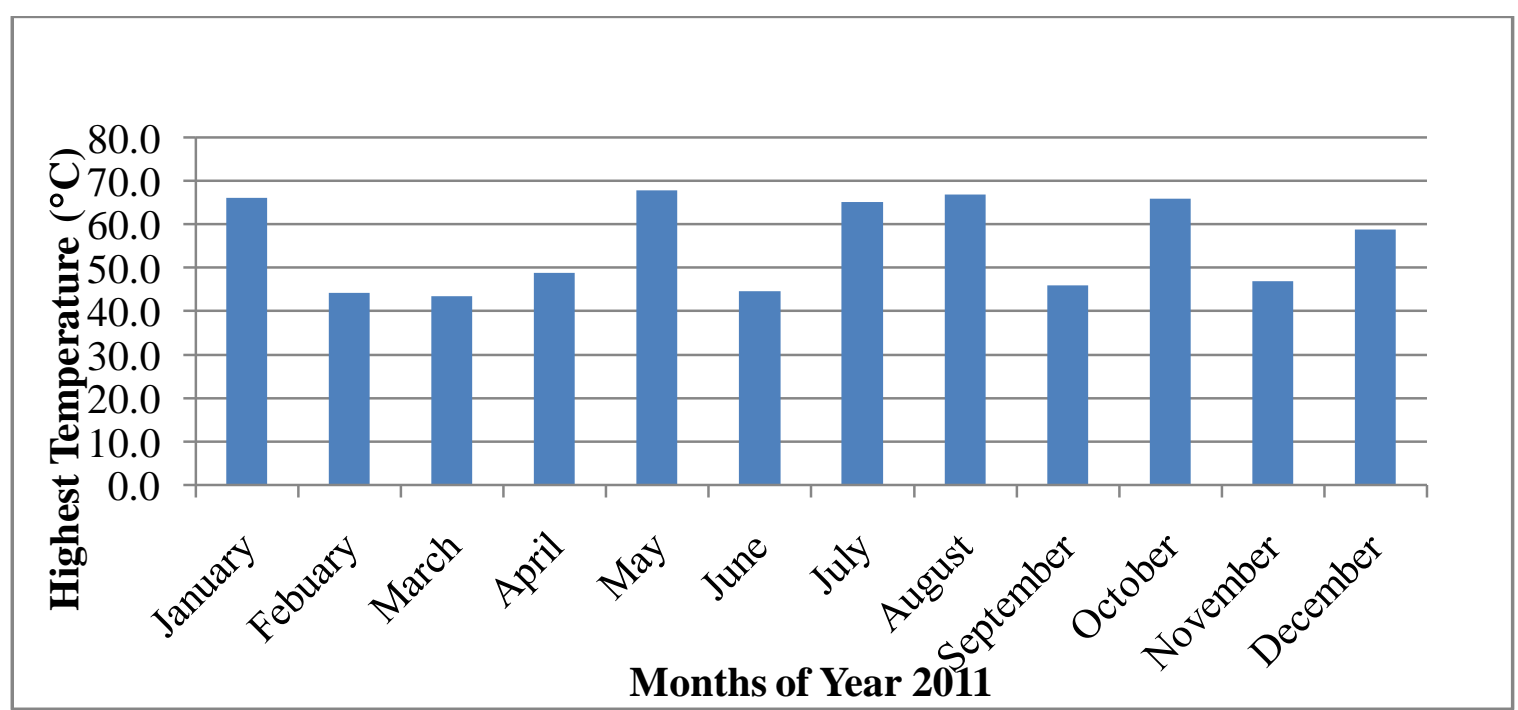

Figure 8: Graph of Highest Temperature $\left({ }^{\circ} \mathrm{C}\right)$ of 11D01 against Months for Year 2011 


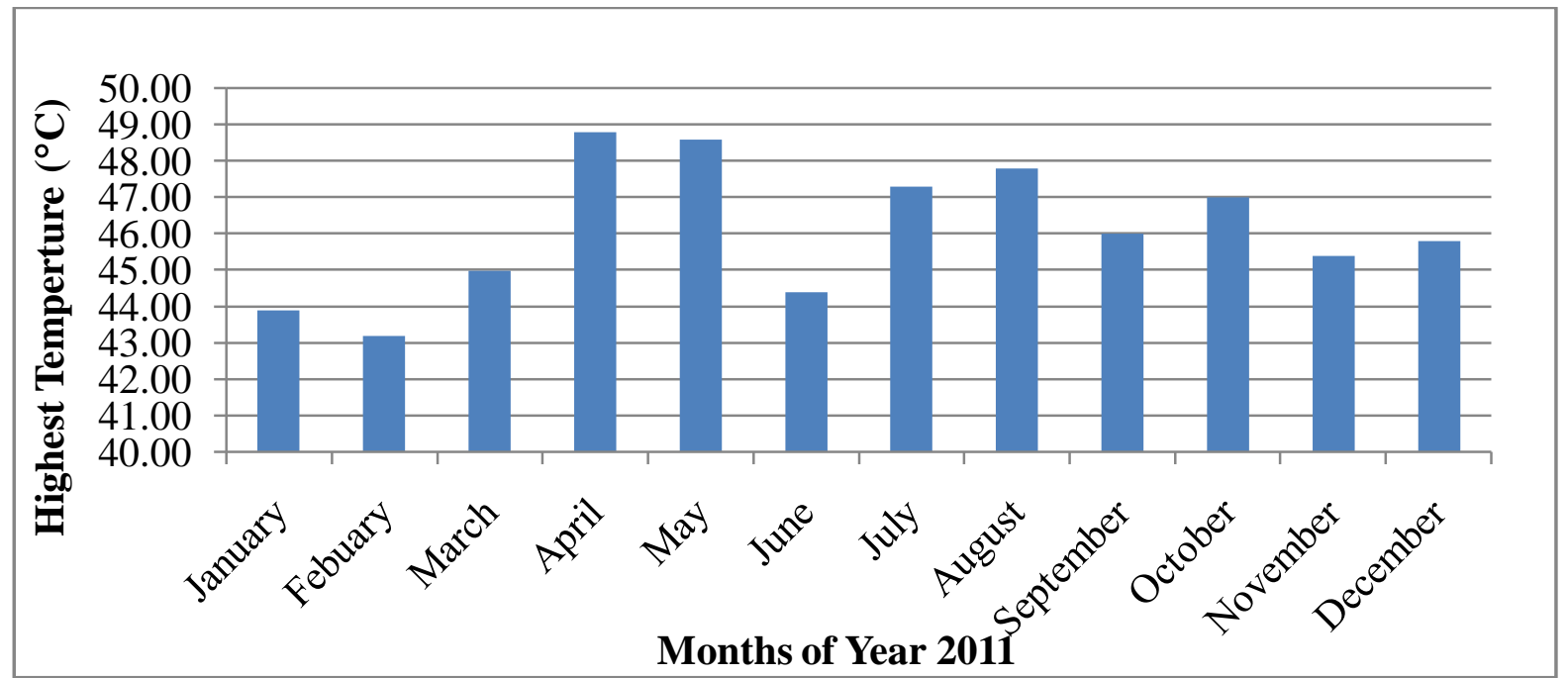

Figure 9: Graph of Highest Temperature $\left({ }^{\circ} \mathrm{C}\right)$ of 11D04 against Months for Year 2011

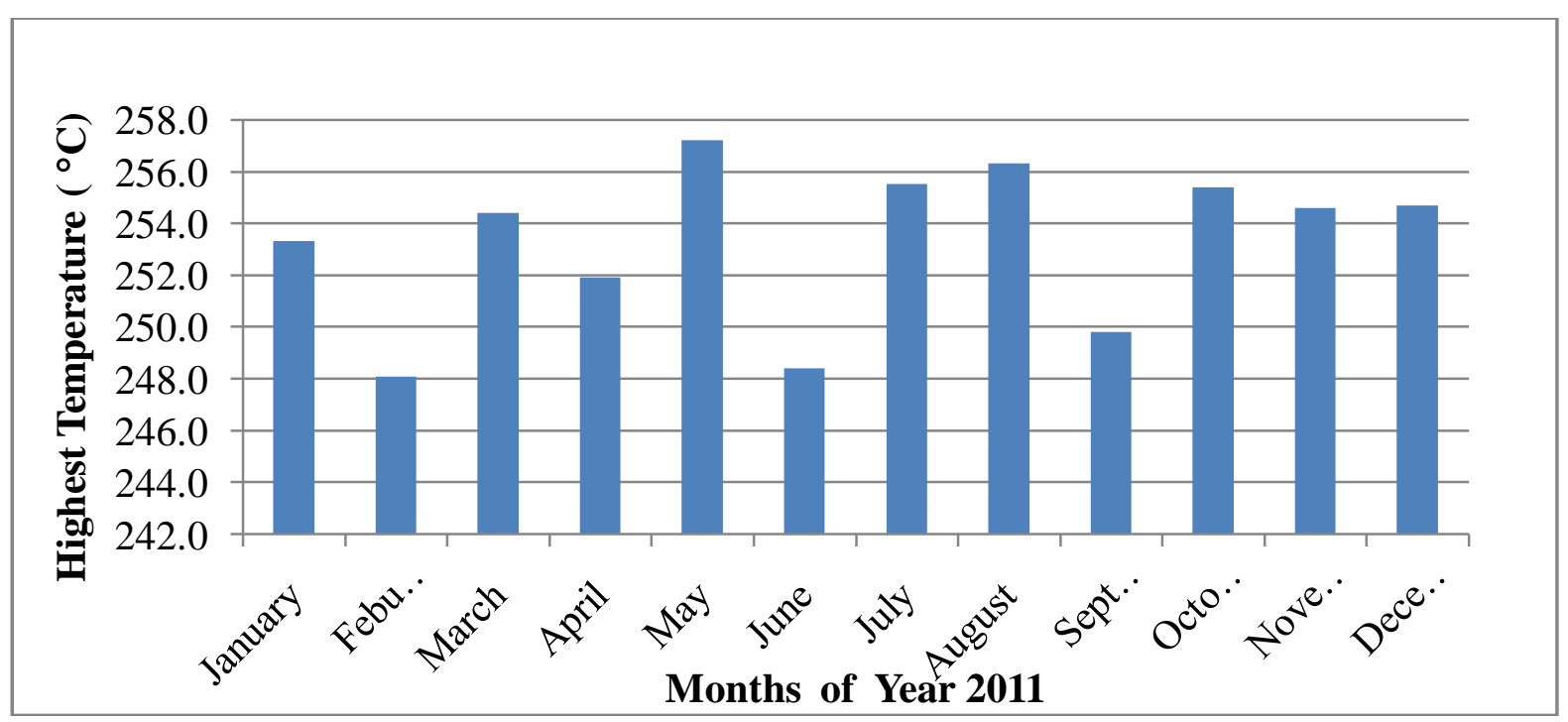

Figure 10: Graph of Highest Bottom Temperature $\left({ }^{\circ} \mathrm{C}\right)$ of $11 \mathrm{C} 01$ against Months of Year 2011

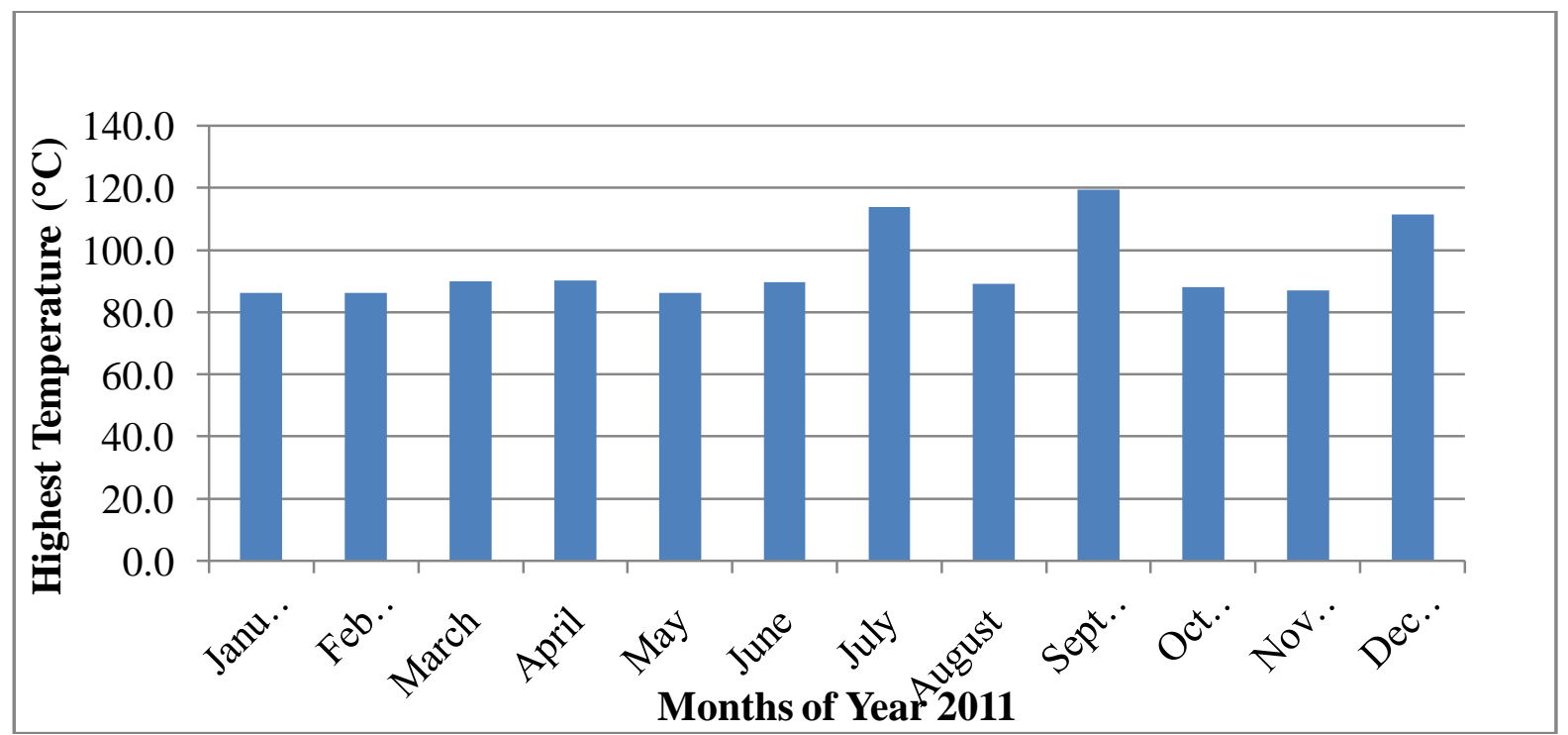

Figure 11: Graph of Highest Top Temperature $\left({ }^{\circ} \mathrm{C}\right)$ of $11 \mathrm{C} 01$ against Months for Year 2011 


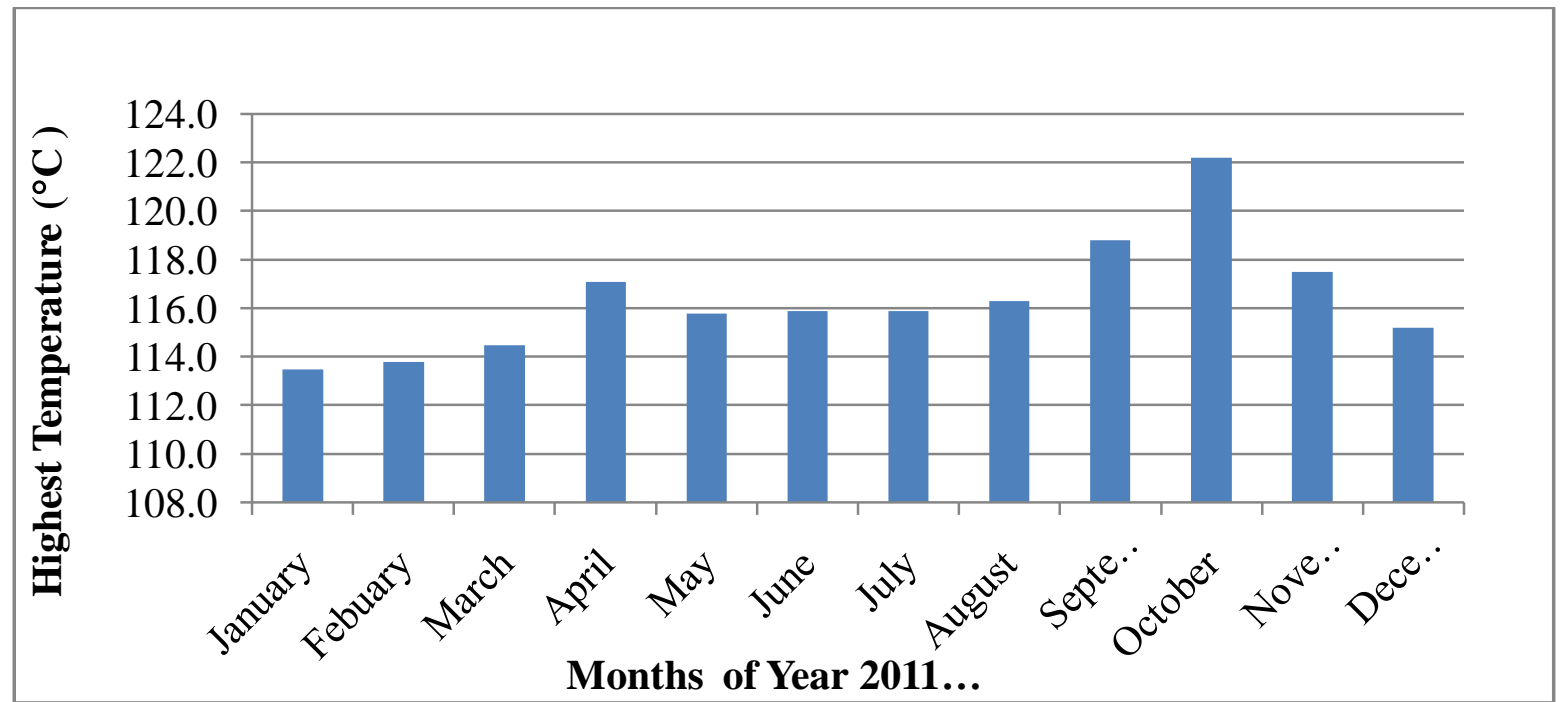

Figure 12: Graph of Highest Bottom Temperature $\left({ }^{\circ} \mathrm{C}\right)$ of $11 \mathrm{C} 02$ against Months for Year 2011

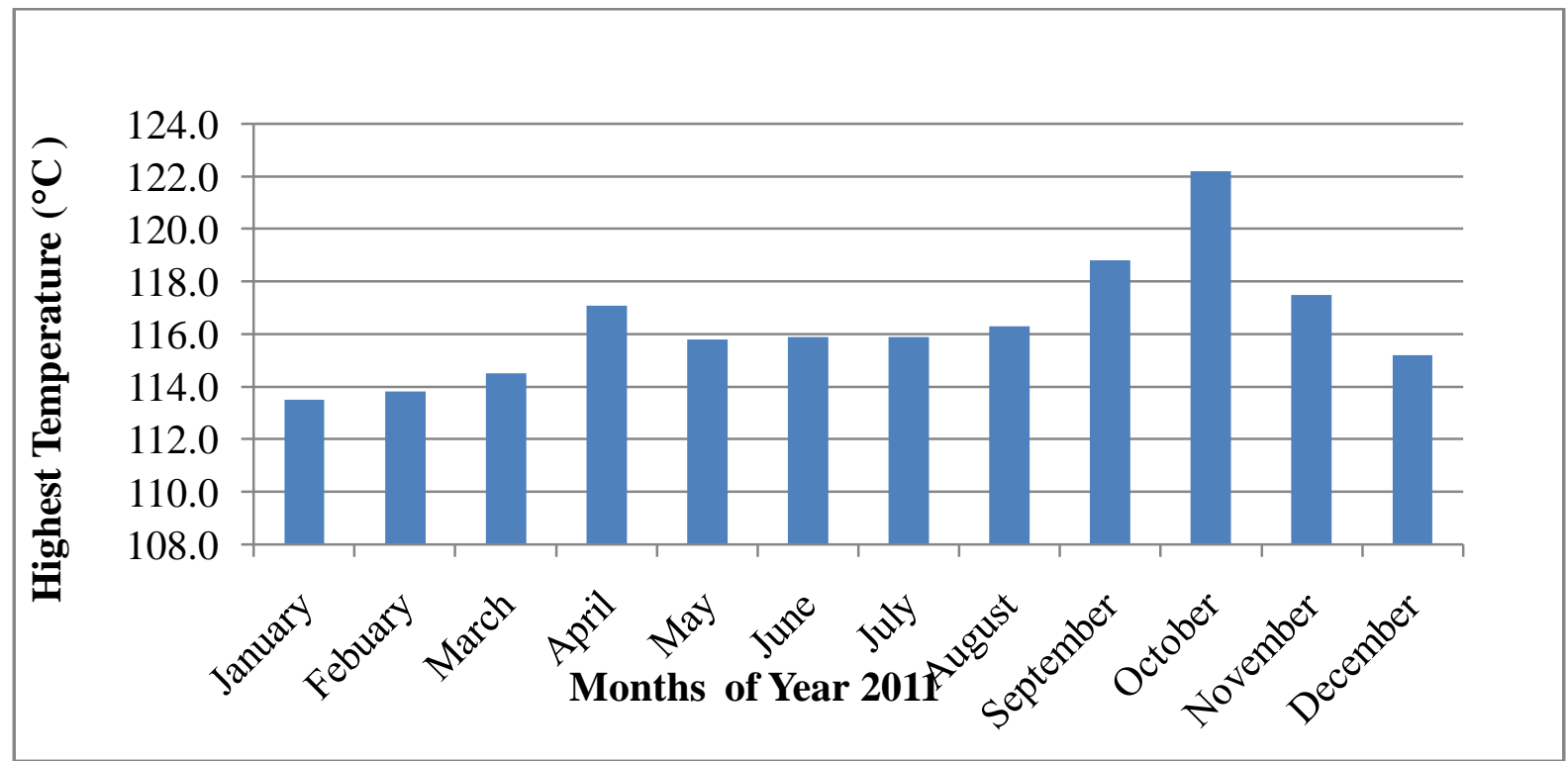

Figure 13: Graph of Highest Top Temperature $\left({ }^{\circ} \mathrm{C}\right)$ of $11 \mathrm{C} 02$ against Months for Year 2011

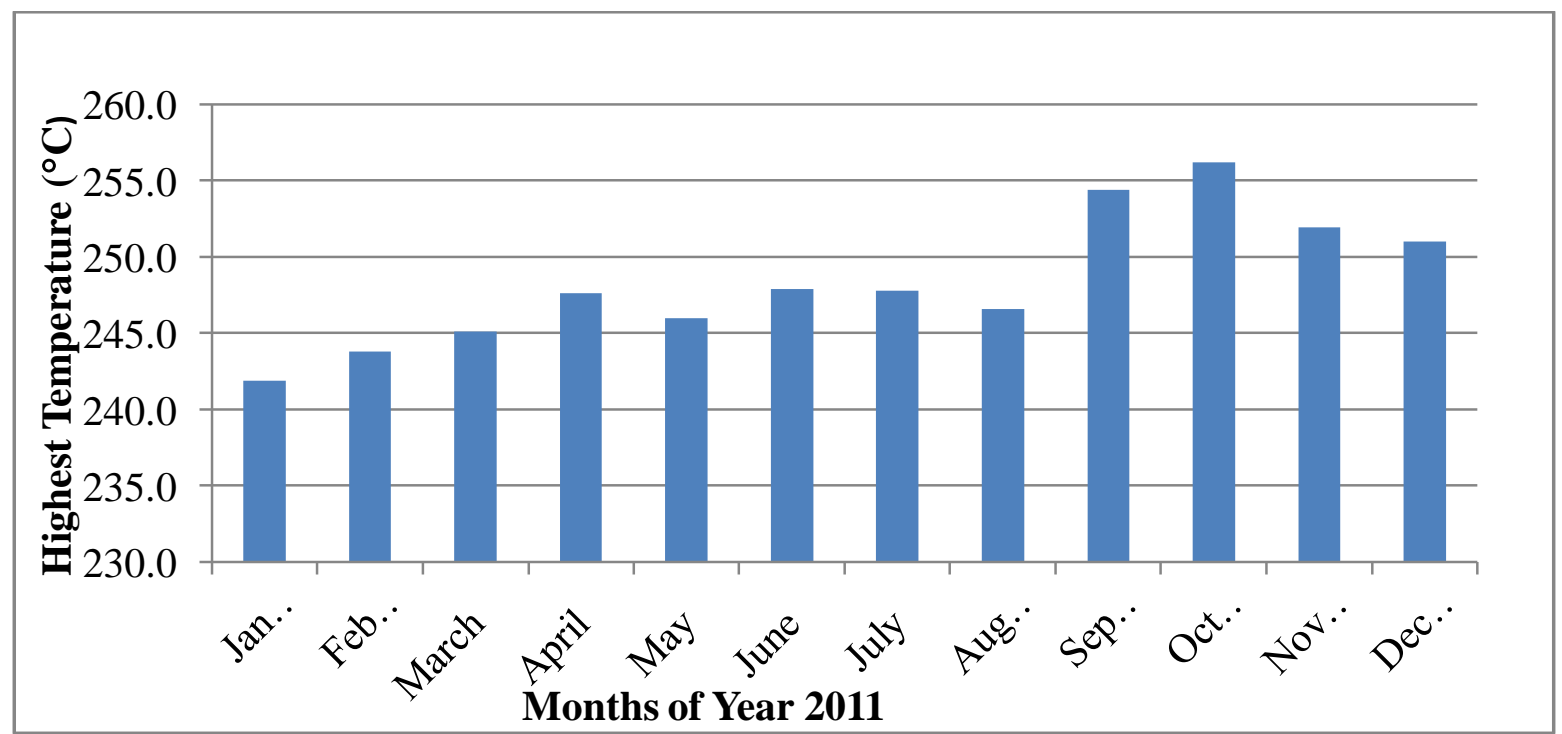

Figure 14: Graph of Highest Temperature $\left({ }^{\circ} \mathrm{C}\right)$ of $11 \mathrm{H} 01$ against Months for Year 2011 
From the result obtained, it was recorded that the average temperatures for a period of one year of the process equipments like surge drum (11D05), reactor charge heater (11H01), NHU reactor (11R01) inlet, NHU reactor (11R01) outlet, feed effluent exchanger(11E01), NHU separator(11D04), NHU stripper(11C01) bottom, stripper (11C01) top, NHU splitter $(11 \mathrm{C} 02)$ bottom, and the NHU stripper reboiler heater $(11 \mathrm{H} 02)$ are $55.1^{\circ} \mathrm{C}, 327.6^{\circ} \mathrm{C}$, $324.1{ }^{\circ} \mathrm{C}, 333.3^{\circ} \mathrm{C}, 181.3^{\circ} \mathrm{C}, 55.5^{\circ} \mathrm{C}, 46.1^{\circ} \mathrm{C}, 253.3^{\circ} \mathrm{C}, 94.7^{\circ} \mathrm{C}, 138.7^{\circ} \mathrm{C}, 116.38^{\circ} \mathrm{C}$, and $248.4^{\circ} \mathrm{C}$. The approximate heat duties for 11H01, 11E01, 11D01, 11DO4, 11H02, 11C01, 11C02 and 11R01 were also recorded as $1.33 \times 10^{8} \mathrm{KJ} /$ day, $1.17 \times 10^{9} \mathrm{KJ} /$ day, $1.14 \times 10^{8} \mathrm{KJ} /$ day, $7.98 \times 10^{7} \mathrm{KJ} /$ day, $8.5 \times 10^{8 \mathrm{~K}} \mathrm{~J} /$ day, $6.0 \times 10^{8 \mathrm{~K}} \mathrm{~J} / \mathrm{day}$, $8.5 \times 10^{7} \mathrm{KJ} /$ day, and $-2.1 \times 10^{7} \mathrm{KJ} /$ day respectively. It is quite obvious that the equipment that constitutes the major source of heat in the Naphtha Hydro - treating Unit is the heat exchangers and heaters.

NB: Temperature measures the flow of heat energy from one body to another. To a degree, the human body system generates some of its own heat through the body metabolism.

The exposure of workers to higher temperature process equipment is a hazard to the health of workers in the sense that the body momentum of the circulatory system changes resulting to heat related illnesses ranging from minor to a more serious and dangerous conditions of dehydration, heat strokes, skin problems like hyperthermia, skin burns, Azospermia and Oligospermia when the time of exposure is prolonged. Heat stroke is an acute condition of hyperthermia that is caused by prolonged exposure to excessive heat.

Figure 3 shows the variation in temperature at various months of the year, this variation in temperature can be said to be attributed to the atmospheric conditions of the year.

Figure 4 gives a clearer view that the heater constitutes one of the major sources of heat emission in the NHU plant despite the changes in atmospheric condition at stipulated month of the year. Figure 5 shows that for the first three months of the year, the temperature difference is quite minimal and towards the end of the year the temperature values were very close. This may be due to the changes in temperature condition of the environment.

Figure 6 shows that at different months of the year, the inlet temperature is almost constant, which explains the temperature at which NHU reactor operates. Figure 7 shows a little deviation from the inlet temperature which may be due to the level of conversion of the reactor feed to product. Figure 8 shows that the highest temperature was obtained during the fifth month of year. Figure 9 illustrates that the highest temperature was obtained in the month of April which is quite hot based on the weather. Figure 10 indicates that the lowest and highest temperatures were $248.1^{\circ} \mathrm{C}$ and $257.2^{\circ} \mathrm{C}$ during the months of February and May which also explains the difference in atmospheric conditions at different period of the year and that the stripper bottom temperature is of a higher one compared to the Figure 11 whose highest temperature was $119^{\circ} \mathrm{C}$ during the month of September. Figure 12 and Figure 13 gives the bottom and top temperatures of the splitter and it also shows that the temperature variation is of a closer range at different periods of the year. Figure 14 shows that the stripper reboiler $(11 \mathrm{H} 02)$ operates between the temperature ranges of $241.9^{\circ} \mathrm{C}$ to $256.2^{\circ} \mathrm{C}$ which is on the high side.

Noise is an undesirable, unpleasant and untimely sound, which can be continuous or intermittent. It may also be said that noise depends on the pre-existing physical and psychological state of the individual. Noise pollution affects everyone, yet this problem is largely ignored by most people. Exposures of workers to high noise level can result to temporary deafness which persists for about 24 hours after exposure to loud noise and may lead to permanent deafness; decreased work efficiency, increased intracranial pressure if the exposure is continuous.

The result presented in Table 4 and 5 show that the average noise exposure of the NHU plant was obtained to be $92.2 \mathrm{~dB}$ measured on the a scale for a shift of 12 working hours which is quite higher than the Occupational Safety and Health Administration (OSHA) of the United States Department of Labor (USDL) standard of $85 \mathrm{~dB}$ for a shift of 8 working hours, hence, it is considered as a pollutant in the NHU plant.

Table 4: Average Values of Noise Pollution in ( Decibel) dB for Year 2011

\begin{tabular}{|c|c|c|c|c|c|c|c|c|c|c|c|c|c|}
\hline & $\stackrel{0}{\stackrel{\Xi}{0}}$ & 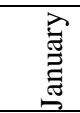 & 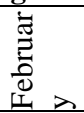 & $\begin{array}{l}\frac{\pi}{0} \\
\stackrel{\Xi}{\Sigma}\end{array}$ & $\overline{\bar{z}}$ & $\stackrel{\vec{\Xi}}{\Sigma}$ & $\stackrel{\Xi}{\Xi}$ & $\frac{\partial}{\Xi}$ & 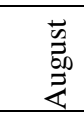 & 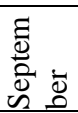 & $\begin{array}{l}\overline{0} \\
\stackrel{0}{0} \\
\stackrel{0}{0} \\
0\end{array}$ & $\begin{array}{l}\tilde{E} \\
\overline{0} \\
\dot{z} \\
\bar{\Delta}\end{array}$ & 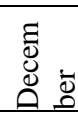 \\
\hline 11P02A & & 93.2 & 95.7 & 92.5 & 93.6 & 93.9 & 94.3 & 95.9 & 96.7 & NIL & 94.6 & 91.0 & 80.5 \\
\hline 11P03B & & 88.9 & 90.2 & 94.8 & 86.1 & 89.3 & 95.9 & 97.6 & 97.8 & 94.0 & NIL & NIL & NIL \\
\hline 1104B & & 90.5 & 90.3 & 90.8 & 86.7 & 90.9 & 93.6 & 97.7 & 96.7 & NIL & 94.1 & 93.9 & 80.7 \\
\hline Average values & & 90.9 & 92.1 & 92.7 & 88.8 & 91.3 & 94.6 & 97.1 & 97.0 & 94.0 & 94.3 & 92.4 & 80.6 \\
\hline \multicolumn{14}{|c|}{ bel) dB for Months of Year 2011} \\
\hline Months & \multicolumn{13}{|c|}{ Noise pollution $(\mathrm{dB})$} \\
\hline January & \multicolumn{13}{|c|}{90.9} \\
\hline February & \multicolumn{13}{|c|}{92.1} \\
\hline
\end{tabular}




\begin{tabular}{ll} 
March & 92.7 \\
April & 88.8 \\
May & 91.3 \\
June & 94.6 \\
July & 97.1 \\
August & 97.0 \\
September & 94.0 \\
October & 94.3 \\
November & 92.5 \\
December & 80.6 \\
Average Value & 92.2 \\
\hline
\end{tabular}

Table 6 below is the results obtained on comparison between the calculated and the process flow diagram (PFD) heat duties. It is was observed that the calculated heat duties for the NHU reactor charge heater and NHU feed effluent exchanger is higher than that in the process flow diagram which indicate that workers are exposed to a higher heat emission hazard. The calculated heat duties for the NHU stripper, NHU splitter, and the NHU reactor is much lesser than that on the process flow diagram which clearly explains that it is within the process specification. The negative sign indicates that the operation of the NHU plant is on the exothermic side of heat.

Table 6: Comparison between the Calculated and the PFD Heat Duties.

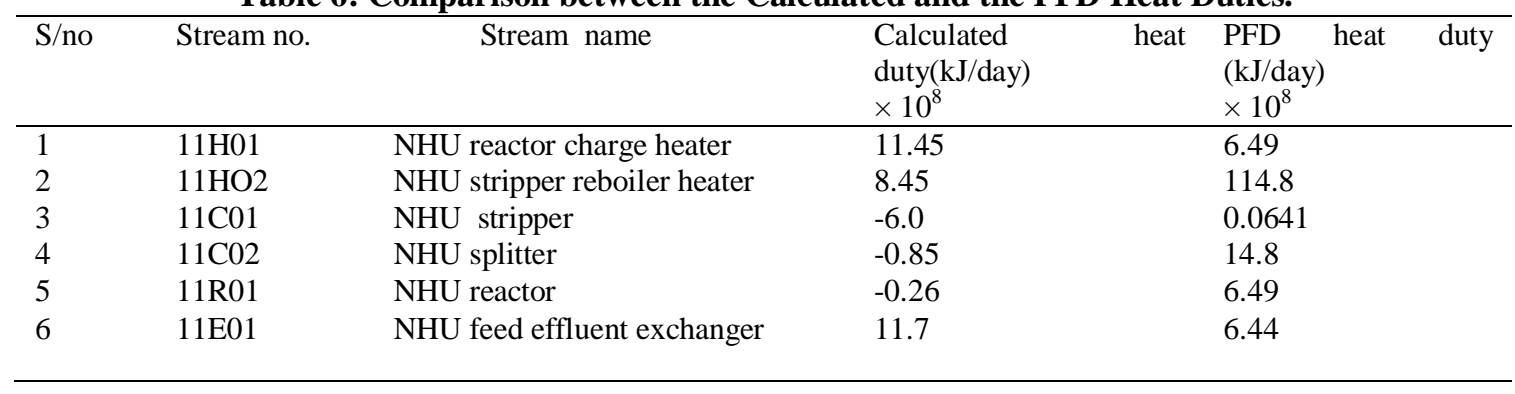

\section{Conclusion}

The safety evaluation of the Naphtha Hydro - treating Unit (NHU) of the Kaduna Refining and Petrochemical Company Nigeria, was ascertained through the formal safety review method of the unit. Within the limit of the data available for this research, it can be concluded that the major hazards associated with the NHU plant are emissions in the form of heat and noise pollution. Based on these, workers in the NHU plant stand the risk of having health problems like dizziness, headache, nausea, respiratory arrest, unconsciousness, mutagen, dermatitis, conjunctivitis, pulmonary irritation, deafness, high blood pressure, abnormal conscience state of mind and even death. Hence, chronic exposure of workers to these emissions from the Naphtha Hydro treating Unit is considered unsafe for workers.

\section{Acknowledgement}

Glory is to Allah (SWT) for his guidance and grace.

\section{References}

[1]. A.I.Ch.E. "Chemical Process Quantitative Risk Analysis" (2000)

[2]. A.I.Ch.E. "Process Equipment Reliability Data," 1989

[3]. California Division of Mines and Geology, Seismic Shaking Hazard Maps of California, Map Contra Costa County. Safety Elements of the General Plan (1995 - 2010). July 1996.

[4]. Chiyoda, S. (1980). "Offshore Projects Gulf Oil Field Directory".

[5]. Gary, J.H., and Handwerk, G.E. (1984). Petroleum Refining Technology and Economics (3 ${ }^{\text {rd }}$ ed.). Marcel Dekker, Inc.

[6]. Hartman, E.L., Hanson, D.W., and Weber, B. Hydrocarbon Proc. 1998, 77.

[7]. Harwood, 1989. "Present Practices of Highway Transportation of Materials", FWHA-RD89-013 Kletz, T. (1985). "An Engineers View of Human Error".

[8]. Lees, F, 1992. "Loss Prevention in Process Industries," Vol 1.

[9]. Prestvi, R., Kjell, M., Knut, G., and Anders, H. (2004). "Compositional Analysis of Naphtha and Reformate."

[10]. Catalytic Naphtha Reforming. USA: Press. Pp. 2-3.

[11]. Sadighi, S., Reza, S.S.M., Ghabouli, O. and Bahmani, M. (2009). "Revamp on the Naphtha Hydrotreating Process in an Iranian Refinery." Petroleum and Coal. 01/2009. Page 45 - 50

[12]. U.S. DOT (2000). National Transportation Statistics.

[13]. U.S. DOT (2002). Hazardous Materials Safety, Hazardous Materials Information System.
} 